\title{
Detection of Porcine Epidemic Diarrhea Virus Using Polymerase Chain Reaction and Comparison of the Nucleocapsid Protein Genes among Strains of the Virus
}

\author{
Shuichi KUBOTA, Osamu SASAKI, Katsuhiko AMIMOTO, Nobutaka OKADA, Takashi KITAZIMA and \\ Hisao YASUHARA* \\ Division of Veterinary Microbiology, Kyoto Biken Laboratories, 24-16 Makishima-cho, Uji, Kyoto 611-0041, Japan \\ (Received 25 August 1998/Accepted 23 February 1999)
}

ABSTRACT. Two pairs of PCR primers were designed to perform nested PCR targetting of a 540 bp fragment of the nucleocapsid (N) protein gene ( $\mathrm{N}$ gene) of porcine epidemic diarrhea virus (PEDV). The $\mathrm{N}$ gene of PEDV was amplified with 4 PEDV strains and 11 small intestines of PEDV-infected piglets collected from 2 farms in Kagoshima prefecture, Japan. Nucleotide sequences of the PCR products from a Korean and two Japanese strains (KKN96-1 and S1) of PEDV isolated in 1993 and 1996, respectively, were almost identical. These results suggest that the PCR is an available tool for detection of PEDV from pigs in the field, and that the two Japanese strains (KKN96-1 and S1) were genetically similar to the Korean strain.—KEY wORDS: nested PCR, nucleocapsid protein gene, porcine epidemic diarrhea virus.

Porcine epidemic diarrhea (PED) virus (PEDV) causes acute enteritis in pigs of all ages, with a pathological impact on pig farming in many countries [3, 19]. The clinical signs of PEDV are characterized by severe diarrhea in pigs and transmissible gastroenteritis (TGE) virus (TGEV) causes similar clinical signs making PED and TGE, difficult to differentiate from each other [18, 19].

In Japan, a PED-like disease first occurred in a farm in February, 1982 [24]. Subsequently, outbreaks of PED or PED-like disease were widely observed during the early 1980s [12]. In February, 1996, epidemics of diarrhea in piglets caused by PEDV infection suddenly broke out on numerous farms in Kagoshima prefecture, Japan.

In Korea, etiological surveys of porcine acute diarrhea in 1992 and 1993 revealed that PEDV infections were widespread [14].

Immunofluoresence and ELISA tests for the detection of PEDV antigens and antibodies have been developed already [2]. Recently, the polymerase chain reaction (PCR) has come into general use for the rapid detection of microbial pathogens and clinical diagnostics because of its high specificity and sensitivity [16]. The nucleotide sequence of the $\mathrm{N}$ gene shows high homology among the same species of coronavirus. And additionally, the $\mathrm{N}$ gene has the advantage of replication in virus infected cells [22, 23]. Therefore, the $\mathrm{N}$ gene could be a suitable target gene for PCR [26].

Here we report the development of a nested reverse transcriptase PCR (RT-PCR) targeting a $540 \mathrm{bp}$ fragment of the $\mathrm{N}$ gene of PEDV for the detection of PEDV RNA in small intestinal contents of pigs. Comparison of necleotide sequences of the $\mathrm{N}$ gene between Japanese and Korean strains was also investigated.

The PEDV CV777 strain [18], JMe2 strain [10], a Korean

\footnotetext{
* Correspondence to: Yasuhara, H., Division of Veterinary Microbiology, Kyoto Biken Laboratories, 24-16 Makishimacho, Uji, Kyoto 611-0041, Japan.
}

strain isolated in 1993 [13] and our isolates designated KKN 96-1 and S1 strains isolated in 1996 from the small intestines of newborn piglets with diarrhea collected from $\mathrm{N}$ and $\mathrm{S}$ farms in Kagoshima prefecture, respectively, by methods described previously [8], were used in this study. The TGEV TO160 [4], SH [5], and Adt-44 (unpublished data) strains, and the hemagglutinating encephalomyelitis virus (HEV) ONS-204 strain [6] were also used.

Viral RNA was extracted from these tissue cultureadapted viruses and small intestinal contents from piglets using TRIZOL LS Reagent (GIBCO BRL Life Technologies Inc., U.S.A.).

cDNA was synthesized in a $20 \mu l$ reaction mixture containing extracted RNA, $50 \mathrm{mM}$ Tris- $\mathrm{HCl}(\mathrm{pH} \mathrm{8.3),} 75$ $\mathrm{mM} \mathrm{KCl}, 10 \mathrm{mM}$ DTT, $3 \mathrm{mM} \mathrm{MgCl} 2,0.5 \mathrm{mM}$ each of dATP, dGTP, dCTP and dTTP, $200 \mathrm{U}$ of SUPERSCRIPTTM II RNase $\mathrm{H}^{-}$Reverse Transcriptase (GIBCO BRL) and 2 $\mu \mathrm{M}$ PEDV/N-R primer (Fig. 1). The reaction mixture was incubated at $42^{\circ} \mathrm{C}$ for $50 \mathrm{~min}$ and heated at $70^{\circ} \mathrm{C}$ for $15 \mathrm{~min}$ to denature the reverse transcriptase.

The oligonucleotide primers for PCR, PEDV/N-F, PEDV/ N-R, PEDV/N-F2 and PEDV/N-R2 primers, are shown in Fig. 1.

Five $\mu l$ of cDNA served as the first PCR template. Primers PEDV/N-F and PEDV/N-R, $2.5 \mathrm{U}$ of Taq polymerase (Takara), $0.25 \mathrm{mM}$ dNTPs, $2.5 \mathrm{mM} \mathrm{MgCl}_{2}, 50$ $\mathrm{mM} \mathrm{KCl}$, and $10 \mathrm{mM}$ Tris $\mathrm{HCl}(\mathrm{pH} 8.3)$ were added to the template in a final volume of $50 \mu \mathrm{l}$. The reaction procedure, under a programmed temperature control system (MJ Research, Inc., Massachusetts, U.S.A.) is shown in Fig. 1b. Five $\mu l$ of the product from the first PCR served as the template for the second PCR. The same mixtures except template were used for the second PCR. The cycling parameters of the second PCR are shown in Fig. 1b. After amplification, $10 \mu l$ of each sample was subjected to agarose gel electrophoresis with or without restriction enzyme digestion.

To confirm the specific amplification of the $\mathrm{N}$ genes of 
a)

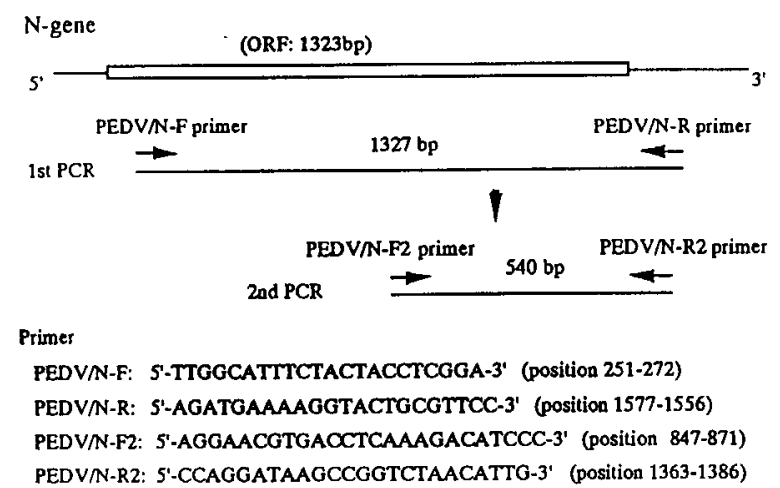

b)

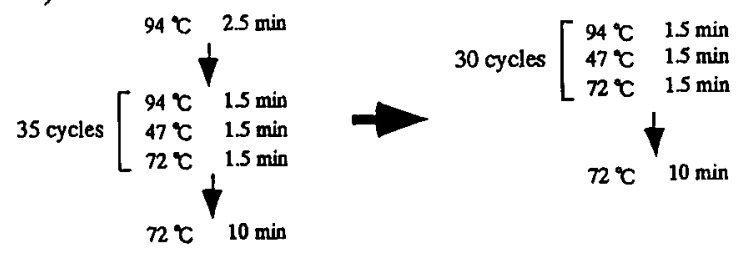

1st PCR 2nd PCR

Fig. 1. (a) Schematic representation of the gene coding for the $\mathrm{N}$ protein [1]. The positions of the oligonucleotide primers used for PCR amplification are indicated by arrow heads. (b) The program of temperature control system for PCR.

PEDV using the detection primers, two PEDV strains, three TGEV strains and one HEV strain were applied as templates for RT-PCR (Fig. 2a). The predicted 540-bp band was detected in the PEDV CV777 and Korean strains, but not in either TGEV or HEV (Fig. 2a). The PEDV JMe2 strain was also positive by RT-PCR, and the 540-bp band could be detected up to $10^{3} \mathrm{TCID}_{50} / \mathrm{m} l$ of the JMe 2 strain in this assay (data not shown). The PCR-amplified DNAs were confirmed by restriction enzyme digestion with Dra I, Eco RI and Pst I (Table 1) and nucleotide sequence determination [11] (Fig. 3). The sizes of the fragments of the Korean strain after digestion with Dra I and Eco RI were consistent with those of the CV777 strain, but the Korean strain was not digested with Pst I (Table 1).

The predicted 540-bp band was also detected for the KKN 96-1 strain (Fig. 2b), and restriction patterns of the PCR products by Dra I, Eco RI and Pst I were the same as those of the PCR products of the Korean strain (Table 1). The nucleotide sequence of the PCR product is shown in Fig. 3. The homology of cDNAs between the KKN 96-1 and CV777 strain was $97.2 \%$.

Eleven samples of small intestines of PEDV-infected piglets collected from two farms ( $\mathrm{N}$ and $\mathrm{S}$ farms; confirmed by seroconversion) in Kagoshima prefecture and 5 samples a)

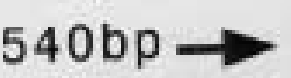

M12 3445667

b)

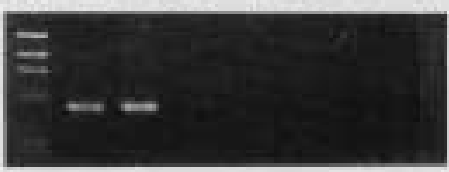

123

$540 \mathrm{bp}$

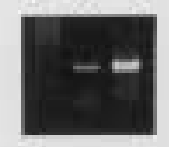

Fig. 2. (a) PCR amplification of the $\mathrm{N}$ genes of porcine coronaviruses. Lane 1, PEDV CV777 strain; lane 2, PEDV Korean strain; lane 3, TGEV SH strain; lane 4, TGEV Adt-44 strain; lane 5, TGEV TO160 strain; lane 6, HEV ONS-204 strain; lane 7, distilled water; lane M, marker DNA (ØX174 phage DNA digest with Hae III). (b) PCR amplification of the N gene of PEDV. Lane 1, distilled water; lane 2, CV777 strain; lane 3, KKN 96-1 strain.

Table 1. The size of digested second PCR amplified fragments

\begin{tabular}{clcc}
\hline \multirow{2}{*}{ Virus strain } & \multicolumn{3}{c}{ Enzyme pattern digested with } \\
\cline { 2 - 4 } & \multicolumn{1}{c}{ Dra I } & Eco $\mathrm{RI}$ & \multicolumn{1}{c}{ Pst I } \\
\hline CV777 & $0.31^{\mathrm{a})}, 0.23$ & $0.50,0.04$ & $0.37,0.17$ \\
Korean & $0.31,0.23$ & $0.50,0.04$ & 0.54 \\
KKN96-1 & $0.31,0.23$ & $0.50,0.04$ & 0.54 \\
\hline
\end{tabular}

a) Kilobases.

of small intestines of piglets collected from a PEDV free farm ( $\mathrm{T}$ farm; confirmed by seroconversion) in Hyougo prefecture were tested by RT-PCR to detect the N gene of PEDV. The $\mathrm{N}$ genes of the virus were detected from the $\mathrm{N}$ farm (7/7) and the $\mathrm{S}$ farm (4/4), but not from the $\mathrm{T}$ farm $(0 /$ 5) (data not shown).

Restriction patterns of the PCR products from N-1 (small intestinal contents of the $\mathrm{N}$ farm) and $\mathrm{S}-1$ (small intestinal contents of the $\mathrm{S}$ farm) were the same as those of the Korean strain (data not shown). Furthermore, the nucleotide sequences of PCR products from the S1 strain (isolated from S-1) were determined and compared with those of the CV777 strain (Fig. 3). The sequence homologies between the S1 and CV777 strains were calculated as $97.4 \%$ at the nucleotide level (Fig. 3).

The nucleotide sequences of the PCR products of the S1 and Korean strains were also compared. The results showed $100 \%$ homology between these two strains (Fig. 3).

PED has been diagnosed by detection of virus and/or its 


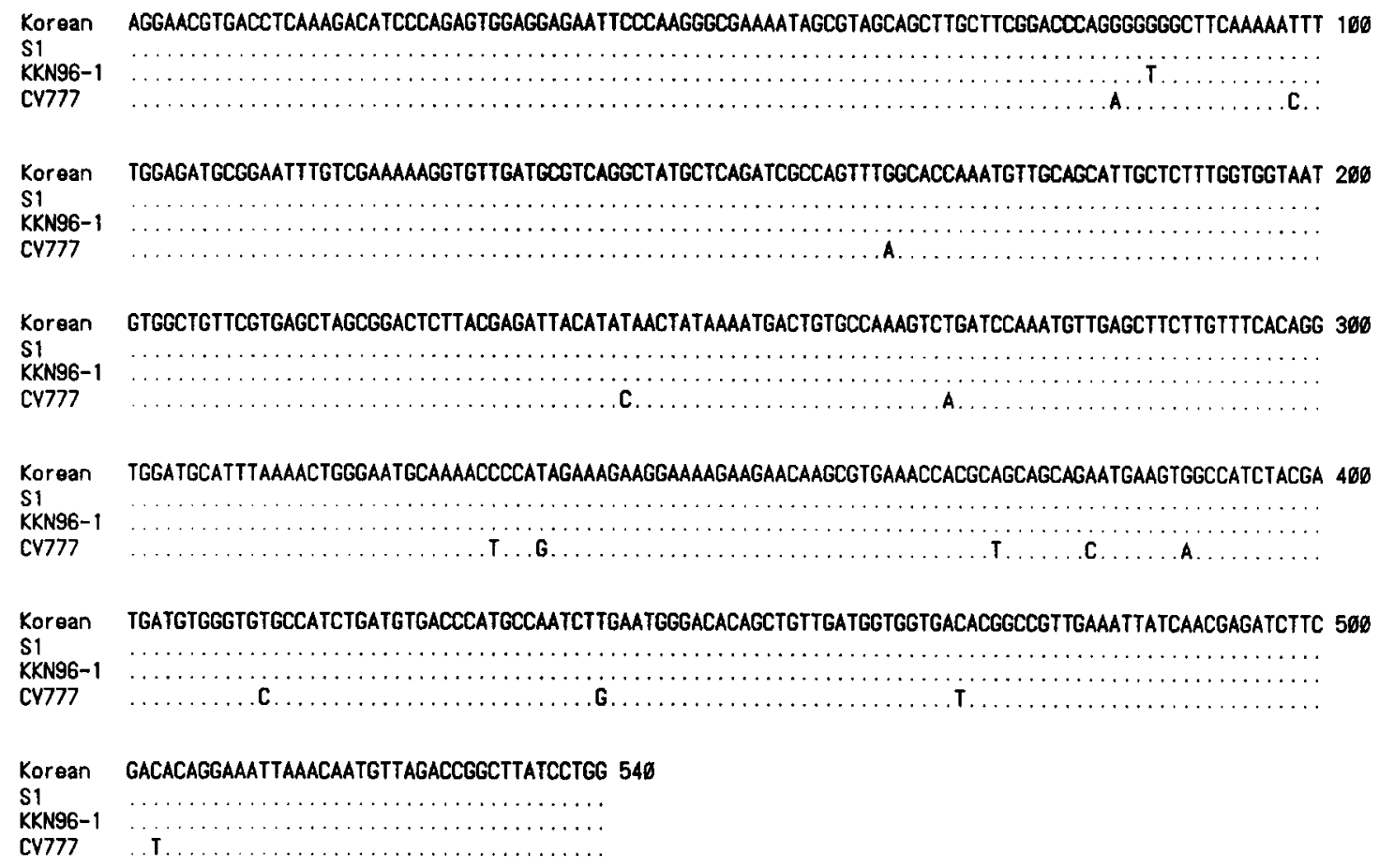

Fig. 3. The nucleotide sequence alignment of the $\mathrm{N}$ gene of the Korean, S1, KKN 96-1 and CV777 strains. Dots indicate identical nucleotides.

antigens in feces, or by demonstration of seroconversion, using indirect immunofluorescence test (IIFT) [7, 20, 21], immunofluorecence blocking test (IFBT) [27], enzymelinked immunosorbent assay (ELISA) blocking test [2] and ELISA [9]; but these methods are time-consuming and require expertise. Recently, PCR has commonly been used to detect genes of viruses, bacteria and protozoa $[17,25$, 26], for time-saving and because of the limited availability of samples. In this study, two pairs of synthetic oligonucleotide primers for PCR amplification, which are localized within the mRNA coding the PEDV N protein, were designed. These primers could detect the $\mathrm{N}$ gene from not only the PEDV CV777 strain but also the Korean and Japanese strains. The primers appeared to work specifically for PEDV, since no detectable amplification of DNAs was observed when the primers were applied to TGEV, HEV and PEDV negative samples.

Kweon et al. developed a rapid method for detecting PEDV by RT-PCR using the membrane (M) gene [15]. In this report, we have described a nested PCR method using the $\mathrm{N}$ gene to detect PEDV from small intestinal contents of naturally infected pigs in order to develop a method with higher sensitivity. We employed the $\mathrm{N}$ gene for the PCR target because the cells infected with coronavirus are most abundant in virus mRNA encoding the $\mathrm{N}$ protein [22, 23]. By this method, we could detect the $\mathrm{N}$ gene of PEDV from all samples of small intestines of piglets collected from PEDV-infected farms. Furthermore, we determined the nucleotide sequences of the amplified products. The nucleotide and amino-acide sequences between a Korean and two Japanese strains (KKN96-1 and S1) were almost identical. These findings indicate that the $\mathrm{N}$ protein and its gene are available for diagnosis of PEDV infections.

Recently, PEDV has been widespread in Japan and Korea. Our data suggested that the Japanese strains isolated in 1996 are genetically very similar to the Korean strain isolated in 1993. Further analysis of the genes of PEDV distributed in other regions is required.

\section{NOTE}

The nucleotide sequence data reported in this paper have been submitted to the DDBJ nucleotide sequence database and have been assigned the accession numbers AB022288 (Korean), AB022288 (S1), and AB007451 (KKN96-1).

ACKNOWLEDGMENTS. The authors thank Dr. C-H. Kweon of the National Veterinary Research Institute, Korea, for kindly providing the PEDV Korean strain, Dr. M. Pensaert of University of Gant Sallsburyiaan, Belgium, for kindly providing the PEDV CV777 strain, and Miss Y. Miyanaga and Miss M. Hayashida of Kyoto Biken Laboratories for technical assistance.

\section{REFERENCES}

1. Bridgen, A., Duarte, M., Tobler, K., Laude, H. and Ackermann, M. 1993. J. Gen. Virol. 74: 1795-1804.

2. Callebaut, P., Debouck, P. and Pensaert, M. 1982. Vet. 
Microbiol. 7: 295-306.

3. Debouck, P. and Pensaert, M. B. 1980. Am. J. Vet. Res. 41: 219-223.

4. Furuuchi, S., Shimizu, Y. and Kumagai, T. 1975. Natl. Inst. Anim. Health Q. 15: 159-164.

5. Harada, K., Kumagai, T. and Sasahara, J. 1963. Natl. Inst. Anim. Health Q. 3: 166-167.

6. Hirahara, T., Yasuhara, H., Kodama, K., Nakai, M. and Sasaki, N. 1987. Jpn. J. Vet. Sci. 49: 85-93.

7. Hofmann, M. and Wyler, R. 1987. Schweiz. Arch. Tierheilkd. 129: 437-442.

8. Hofmann, M. and Wyler, R. 1988. J. Clin. Microbiol. 26: 2235-2239.

9. Hofmann, M. and Wyler, R. 1990. Vet. Microbiol. 21: 263273.

10. Ishikawa, K., Sekiguchi, H., Ogino, T. and Suzuki, S. 1997. J. Virol. Meth. 69: 191-195.

11. Kubota, S., Kakuda, T., Sugimoto, C., Waltisbuhl, D. and Onuma, M. 1996. J. Protozool. Res. 6: 13-20.

12. Kuwahara, H., Nunoya, T., Samejima, T. and Tajima, M 1988. J. Jpn. Vet. Med. Assoc. 41: 169-173 (in Japanese with English summary).

13. Kweon, C. H., Kwon, B. J., June, T. S., Kee, Y. J., Hur, D. H., Rhee, J. C. and An, S. H. 1993. Kor. J. Vet. Res. 33: 249254.

14. Kweon, C. H., Kwon, B. J., Kang, Y. B. and An, S. H. 1994. Kor. J. Vet. Res. 34: 321-326.
15. Kweon, C. H., Lee, J. G., Han, M. G. and Kang, Y. B. 1997. J. Vet. Med. Sci. 59: 231-232.

16. Mahbubani, M. H. and Bej, A. K. 1994. pp. 307-324. In PCR Technology, Current Innovations (Griffin, H. G. and Griffin, A. M. eds.), CRC Press, Florida.

17. Olive, D. M., 1989. J. Clin. Microbiol. 27: 261-265.

18. Pensaert, M. B. and Debouck, P. 1978. Arch. Virol. 58: 243 247.

19. Pensaert, M. B. 1989. pp. 167-176. In: Virus Infections of Porcine (Pensaert, M. ed.), Elsevier, Amsterdam.

20. Prager, D. and Witte, K. H. 1981a. Tieraerztl. Umsch. 36: 404-414.

21. Prager, D. and Witte, K. H. 1981b. Tieraerztl. Umsch. 36: 477-480.

22. Siddel, S., Wege, H. and ter Meulen, V. 1982. Curr. Top. Microbiol. Immunol. 99: 131-163.

23. Siddel, S., Wege, H. and ter Meulen, V. 1983. J. Gen. Virol 64: 761-776.

24. Takahashi, K., Okada, K. and Ohshima, K. 1983. Jpn. J. Vet. Sci. 45: 829-832.

25. Tanaka, M., Onoe, S., Matsuba, T., Katayama, S., Yamanaka, M., Yonemiti, H., Hiramatu, K., Beak, B., Sugimoto, C. and Onuma, M. 1993. J. Clin. Microbiol. 31: 2565-2569.

26. Yamada, Y. K., Yabe, M., Yamada, A. and Taguchi, F. 1993. Lab. Anim. Sci. 43: 285-290.

27. Witte, K. H. and Prager, D., 1987. Tieraerztl. Umsch. 42 : 817-820. 